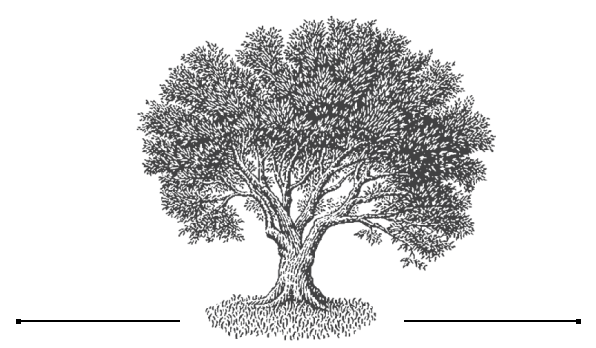

\section{Indirect Speech Acts in the Speech of the Characters of the Tale of Bygone Years}

\author{
Victor S. Savelyev \\ Lomonosov Moscow State University \\ Moscow, Russia
}

\section{Косвенные речевые акты в речи персонажей "Повести временных лет"}

\author{
Виктор Сергеевич \\ Савельев \\ Московский государственный \\ университет им. М. В. Аомоносова \\ Москва, Россия
}

\title{
Abstract
}

The article states that communication in Old Russian as well as in modern Russian discourse is characterized by the use of mono-functional and poly-functional indirect speech acts. Moreover, the important aspect that helps to specify the illocutive functions of indirect speech acts in Old Russian is their verifiability: the verbal or non-verbal response of the interlocutor as well as the frame constructions, which introduce direct speech (preposition). These constructions are also used in the middle of the utterance (interposition) or at the end of the utterance (postposition). The author of the chronicles observes the communicative purposes of both the speaker and the interlocutor, indicating that the given utterance should be regarded as an indirect speech act. By analyzing the use of mono-functional indirect speech acts in the original dialogue fragments of the Tale of Bygone Years, the author works out their typology. The groups of interrogative and non-interrogative indirect speech acts have been singled out, each of them having certain typical characteristics. The semantics of non-interrogative utterances in most cases is connected with the expression of indirect meanings of time and aspect of verbal forms. The use of interrogative utterances as indirect speech acts is mostly connected with the changes not only in the illocutive function, but also in the propositional meaning of the predicative unit: interrogative utterances with negations should be interpreted as affirmative non-interrogative utterances and vice versa. 
The author comes to the conclusion that the use of modern mono-functional indirect speech acts is traditional, since it is identical to their functioning in Old Russian.

Key words

Tale of Bygone Years, mono-functional and poly-functional indirect speech acts

Резюме

В статье устанавдивается, что для древнерусской коммуникации так же, как и для современного руского дискурса, свойственно употребление монофункциональных и полифункциональных косвенных речевых актов. При этом важным аспектом определения иллокутивных функций древнерусских косвенных речевых актов является их верифицируемость: о том, что высказывание воспринимается в качестве косвенного речевого акта, свидетельствует вербальная и/иди невербальная реакция собеседника, а также то, что в рамочных конструкциях, предваряющих и завершающих реплики, автором текста указываются коммуникативные целеустановки говорящего и собеседника. Анадизируя использование монофункционадыных косвенных речевых актов в оригинальных (не восходящих к другим текстам) диалогических фрагментах “Повести временных лет", автор статьи выстраивает их типологию. Выделяются группы невопросительных и вопросительных косвенных речевых актов, для каждой из которых определяются характерные для нее признаки. Семантика невопросительных высказываний в большинстве случаев связана с выражением непрямых видо-временных значений глагольных форм. Использование вопросительных высказываний в качестве косвенных речевых актов чаще всего связано с изменением не только илдокутивной функции, но и пропозитивного содержания предикативной единицы: воспросительные высказывания с отрицанием должны восприниматься в качестве утвердительных невоспросительных высказываний, и наоборот. Автор приходит к выводу, что исподьзование современных монофункциональных косвенных речевых актов имеет традиционный характер, будучи тождественным их функционированию в древнерусской речи.

\section{Ключевые слова}

Повесть временных лет, монофункциональные и полифункциональные косвенные речевые акты

\section{State of the Art}

One of the basic concepts used in modern communicative science is the notion of the indirect speech act (hereafter-ISA). The ISAs, described in terms of the theory of speech acts [СЕРль 1986], will be regarded as utterances not with direct illocutionary functions, those "arising from the literal meaning of a sentence" [ПАДУчевА 2001: 44], but utterances with indirect functions. The notion of the ISA allows one to allocate within the communicative potential of an utterance, which is a set of its possible illocutionary functions (hereafter- 
IF), the main (direct) one, perceived as devoid of context, and the peripheral (indirect) functions, which are realized in the ISA. The recipient should be able to distinguish between the ISAs and the direct speech acts (hereafterDSA), and adequately interpret the communicative intention of the speaker, incidentally reconstructing the non-explicatory meanings "hidden" in the ISA. The basis of this ability is that "the use of indirect speech acts is, to a greater or lesser extent, conventionalized” [ЛАйонз 2003: 269].

The types of ISAs characteristic of Russian speech have been streamlined during the study of the modern discourse, which is quite natural. Meanwhile, an analysis of the Old Russian texts shows that statements with indirect IF were also used in Old Russian communication.

Let us now turn to the analysis of the dialogue fragments of the Tale of Bygone Years (hereafter-the TBY). ${ }^{1}$

The important aspect that helps to define the illocutive functions of ISAs in Old Russian is their verifiability. On the one hand, the IF of the utterance can be established on the basis of the judgment of the response of the interlocutor, who either gives a response or commits a response action. On the other hand, the chronicle dialogue is preceded and followed by a frame construction, which lists the participants of the communicative act, their communicative goals and perlocutionary effect, the specific features of the given speech act, the physical conditions of communication, the author's assessment of the dialogue, etc. For example, in the following fragment И воєвода нача (Отополчь,

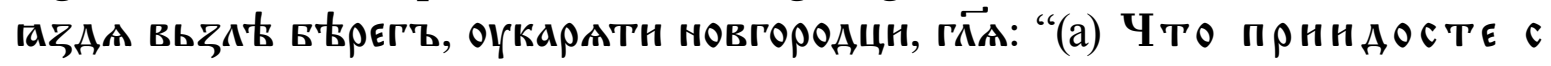
ХРОмьцемь снмь, а вы, плотннци сүще? (b) व прнставнмъ вы

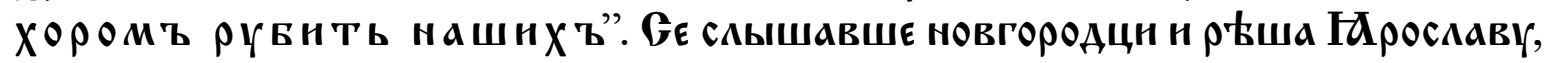

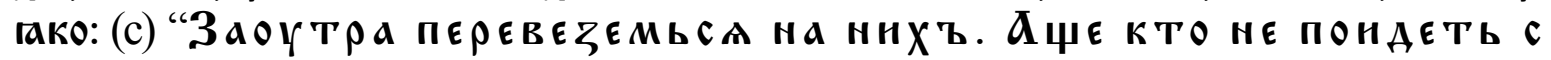

1 The material for this research is the TBY text from the Hypatian Codex published by [ПСРЛ 1908]. In cases when the text of the Hypatian Codex has certain omissions, they are reconstructed in accordance with the Khlebnikov Chronicle (the comparison of the two chronicles is given in the same edition). In cases when the interpretation of the Hypatian Codex is considered to be erroneous by the TBY researchers engaged in the publication of the text, footnotes are provided to the corresponding places in the Khlebnikov Codex and to the chronicles used to reconstruct the Laurentian Codex: the Laurentian, the Radziwill, and the Academic chronicles [ПСРЛ 1926]. The footnotes generally include the Khlebnikov and Laurentian Codex variations, and if only one of them is used, the absence of the second one indicates the coincidence of its interpretation with the interpretation of the Hypatian Codex. Various interpretations can be useful and even necessary for the analysis of the fragments of the $T B Y$, which are difficult to analyze without consulting the texts of different chronicles.

To split the text into words, the edition of [ПСРЛ 1908] has been used. However, to split the text into sentences and to punctuate it (if punctuation marks were nonexistent in the $T B Y$ ), modern standards have been used. The parentheses after the examples specify the year of the quoted fragment (in accordance with the Byzantine chronology accepted in the TBY, from the creation of the world, and the timeline of Christianity). In some cases, it was necessary to give a Modern Russian translation of the corresponding fragments. 


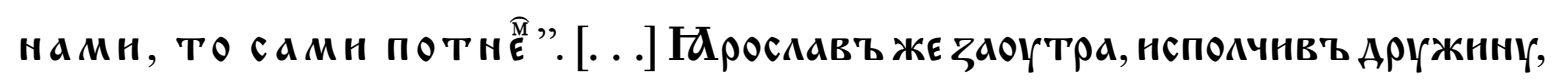
Протнву Св СТУ перевеZесА $(6524 / 1016)$ the voivode of Svjatopolk utters two ISAs, which formally represent an informative question (a) and the message of an intention (b). However, the reaction of the interlocutor (c-the decision to attack the enemy) and the evaluation of the statement IF by the chronicler in the framework structure (огкарлти), as well as the fact that he points to the utterance of the voivode as the cause of the reaction of the Novgorod citizens (се смышавше), confirm that (a) and (b) are indeed ISAs.

The same example shows another important feature of the Old Russian utterances: many of them are illocutionarily poly-functional, which means that the statement can be used simultaneously in several illocutionary functions in the course of one locutionary act. ${ }^{2}$ For example, the utterance (a) is both an evaluative judgment (Зачем вы пришли ... ? = Незачем вам было прихоzums ...!) and an insult (the propositive content of the utterance should appear offensive to the interlocutor: the speaker "lowers" the social status of both the interlocutor and his leader). Statement (b) is also polyfunctional: it not only informs about the intention of the speaker but it is also an insult. While (a) is an ISA (the speaker does not expect an answer, and the interlocutor does not perceive this "question" as an actual question), then (b) is a DSA: in order to understand the offensiveness of (b), it is necessary to link it with (a) and to consider (b) as an intention motivated by a derogatory assessment of the abilities of the interlocutor (вы, плотннци суџе $\Rightarrow$ прнставнмъ вы Хоромъ рувнть нашнхъ).

In this article, we are going to turn to the analysis of mono-functional ISAs-utterances used with one IF. ${ }^{3}$ When identifying the types of ISAs, we first list the basic IF of the utterance (the one in which it could be used as a DSA), and then the indirect IF of the utterance (the one in which it is used as an ISA in the given dialogue fragment).

\section{Typology of Mono-functional Indirect Speech Acts in the Speech of TBY Characters \\ I. Statement Concerning the Present \\ 1. Statement Concerning the Past}

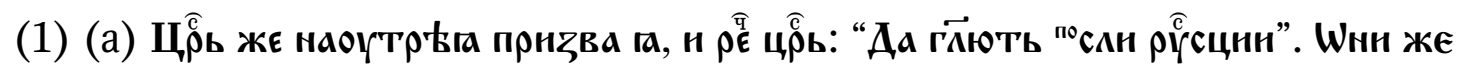

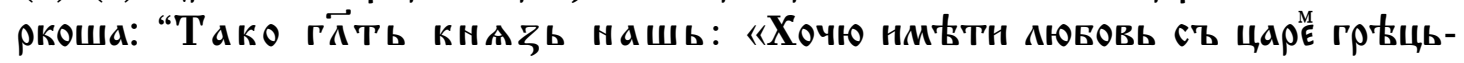

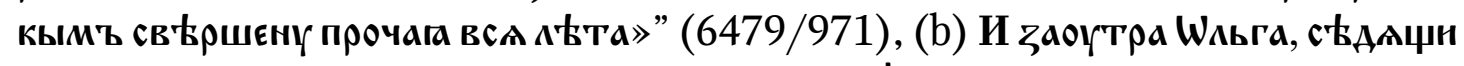
в теремЬ, посла по ГОстн, н прнндоша к ннмъ, ГАюще: "З Оветь вы WАьГа на ч Тे в векнку"

2 For details, see [САВЕЛЬЕв 2016A].

3 The issue of the illocutionarily poly-functional ISA is developed in [САВЕльЕВ 2016А]. 
The speaker informs of an event that took place prior to the moment of speech, using the present tense. The reason for using the present tense is as follows: under the conditions of the violation of the canonical speech situation, he is guided by the time when his interlocutor gets the message. The most illustrative example in this regard is (1a): the Greek king hears the words of the Russian prince as if they were uttered in his presence. ${ }^{4}$

\section{Statement Concerning the Intention of the Speaker}

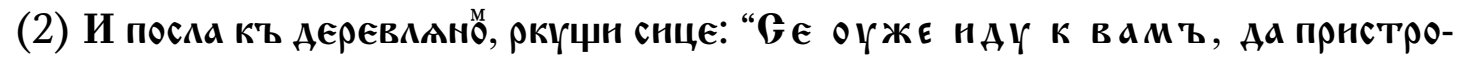
НТЕ МЕАЫ МЬНОГЫ ОУ ГОРОАА, НАЕЖЕ ОГБНСТЕ МУЖА МОЕГО, АА ПОПААЧЮСА НАДЪ гровомъ еै и створю трызні мүжю моемү". Wнн же, слышавше, свезоша меды многы з'Ало (6453/945).

When pronouncing the given utterance, Princess Olga is only going to visit the Drevlyane, however, as in (1a) and (1b), she focuses on the time when the interlocutor gets her message.

\section{Statement Concerning the Intention of a Person Who is not Involved in the Dialogue}

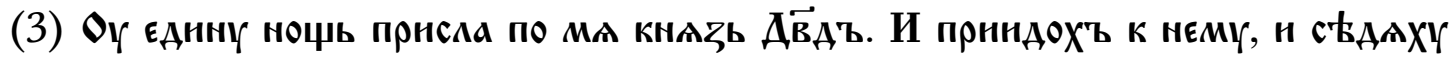

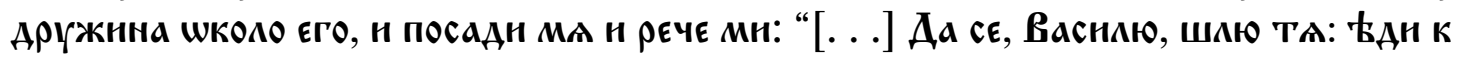

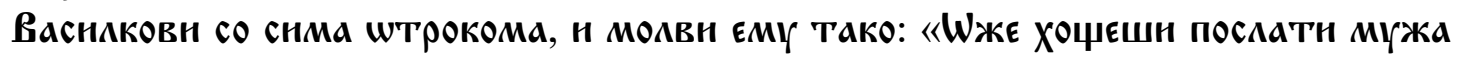
СВОЕГО, Н ВОРОТНТСА ВОАОАНМЕРЪ, ТО ВААМ ТН КОТОРЫН АЮБО ГОРОАТ: АюБО ВСЕВО-

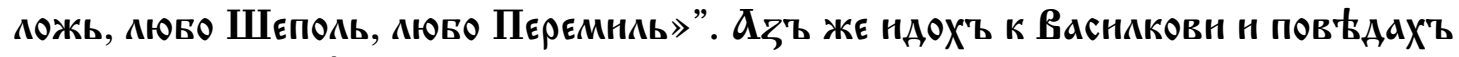

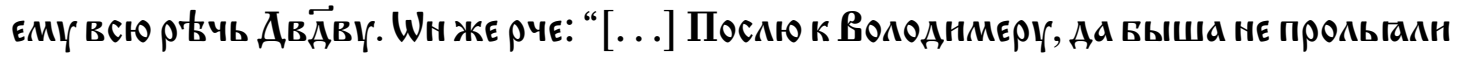

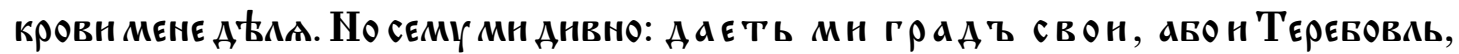
мога волость, ПОЖААВШе и нї'" $(6605 / 1097)$.

Prince Vasilko talks of the proposal of Prince Davyd, pointing out that the latter is giving him one of the cities; however, Prince Davyd has only declared his intention, the implementation of which depends on the further actions of Prince Vasilko. Thus, Prince Vasilko judges the situation as if the condition of

4 The use of the present tense in this type of context is not necessary (for example, По

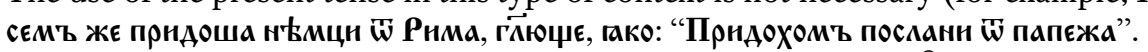

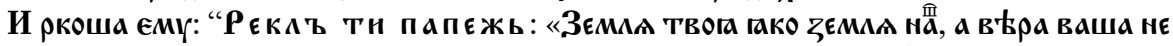
акы вЊра наша». [...]” (6494 / 986), И рекоша новгородци GТТПпоку: “Gє мы,

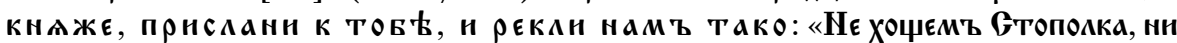
сна єго. [...]»" (6610 / 1102); the choices of verbal forms in the context of distant communication are described in detail in the article [САВЕЛЬЕв 2016Б].

It should also be pointed out that in modern communication, when the rules of the canonical speech situation are violated, we often convey the words of another person using statements like Александра пр осит Вам передать. .., Александра гов орит, что..., Александра обеша а ет Вам..., etc. together with the possible variants like Александра просила Вам передать..., Александра сказала, что. .., Александра обещал а, что. . . 
Prince Davyd has already been fulfilled. In the preceding part of his utterance, Prince Vasilko does agree to fulfill the request of his interlocutor.

\section{Call for Action}

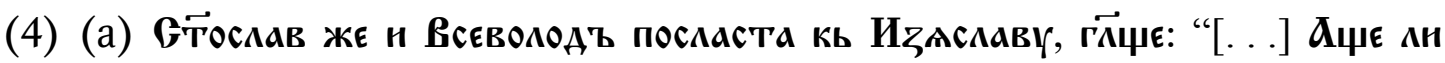

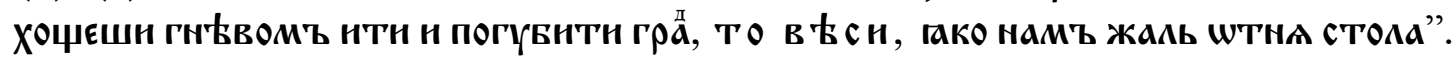
ТО слЫШавЪ, ИЪАСАавЪ ШСТАВН ААХЫ, НАЕ С БОлЕСААВОМЪ, МААО ААХОВЪ ПОЕМЪ

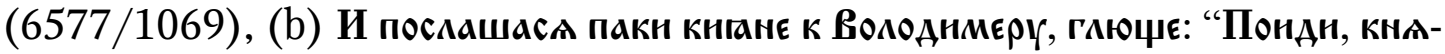

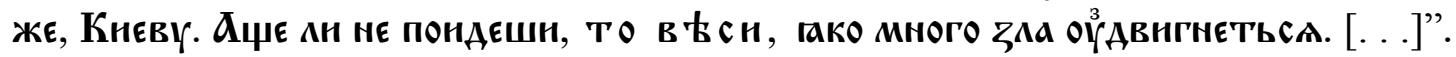

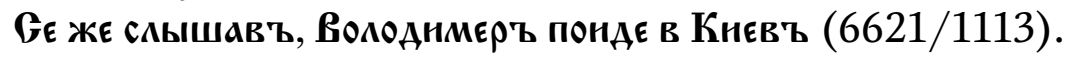

Using the present tense, the speaker urges the interlocutor to perform the action (сам знаешь > знай, прими во внимание). It is significant that the verb used here is в в who supposedly knows himself what is reported, the speaker is "forcing" him to accept his point of view.

\section{Call for Joint Action}

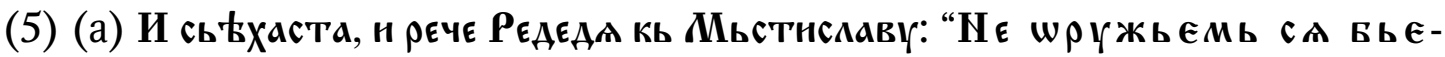
в Њ, НО ворьБОю". И Гаста сА Боротн крБпко (6530/1022), (b) Половци Же,

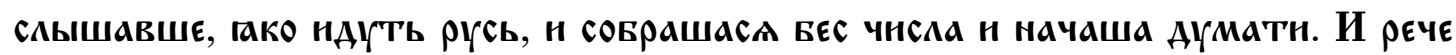
Pусова: "Проснмъ мнра в русн, гако крьпко са нмуТТ внтн с намн, Мы во много за створохомъ Рүскон земан" (6611/1103).

As in (4a) and (4b), in (5a) and (5b) the speaker is talking as if the desirable joint action has already been committed.

6. Institutional Statement

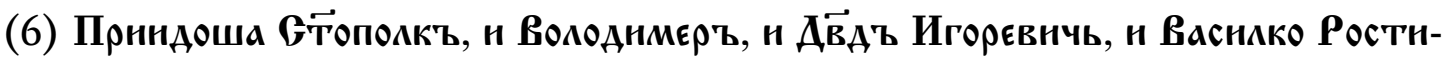
САавНЧЬ, Ї ДВ

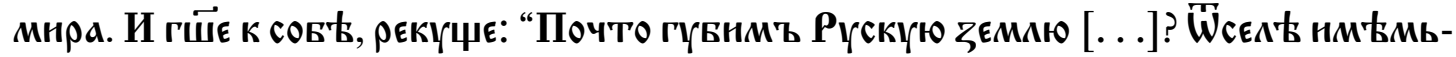

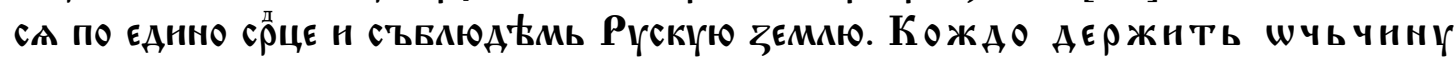

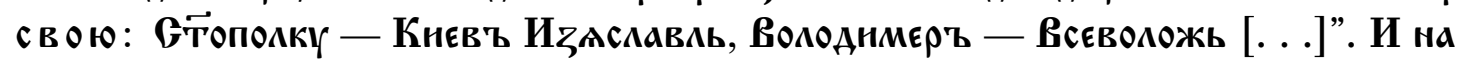
томъ цЊАоваша Хрестъ $(6605 / 1097)$.

In uttering this (6), the speaker is establishing a norm according to which he is going to act in the future. Thus, the present tense describes what should happen after the Council of Princes in Liubech. ${ }^{5}$

In all fairness, it should be pointed out that the Laurentian Codex uses the form $\mathrm{Aa}$ Аєржнть. 


\section{Prediction}

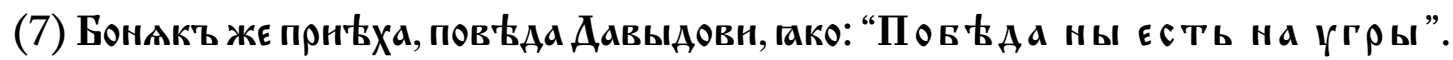

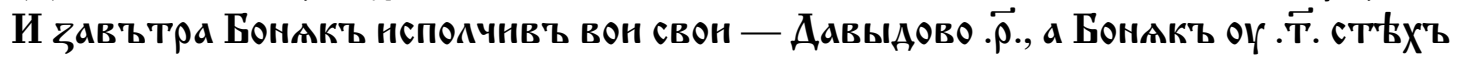

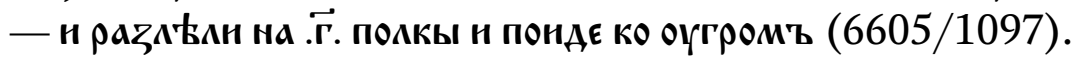

Using the present tense, Bonyak is talking about a victory in a battle which has not yet even started as if it were a fait accompli.

Thus, in most cases the use of the present tense in an ISA allows the speaker to describe the event that has not yet occurred as one that is taking place; to convince the interlocutor that the given event is inevitable.

\section{Statement Concerning the Future \\ 1. Statement Concerning the Present (Present Tense)}

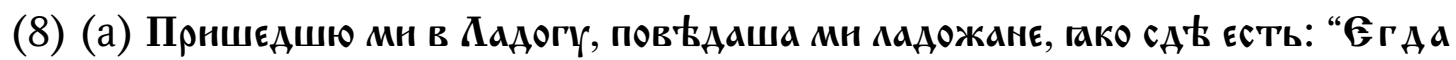

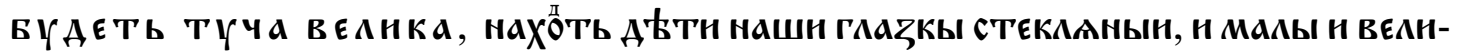

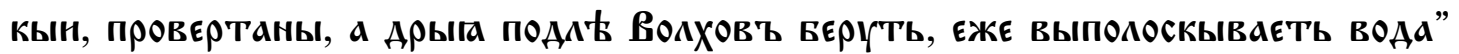

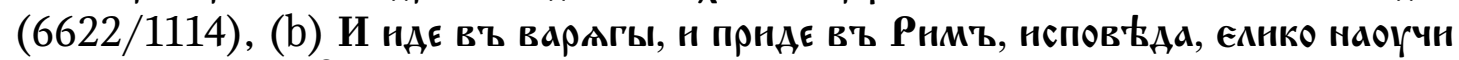

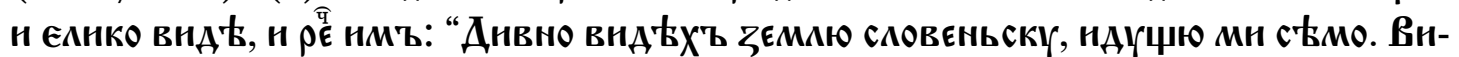

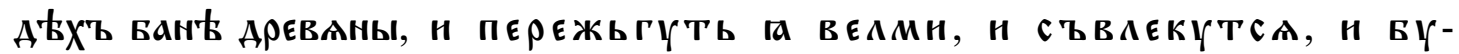

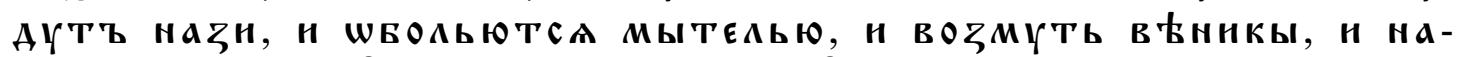

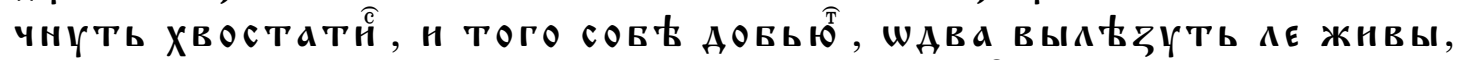

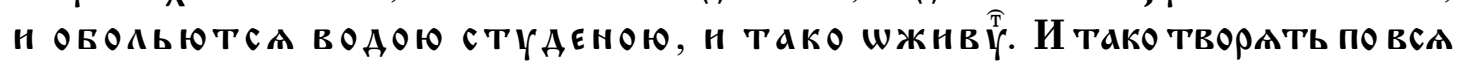
АН̈Н НЕ МүчНМн ННКЫМ ЖЕ [...]".

Such ISAs can be found in fragments of the narrative type of the dialogue: the speaker talks about things that can happen, with the ISA contained in an initial predicative unit (hereafter-PU), which describes the condition of the emergence of such a typical situation (see 8a), or in the main part of the story, which describes the sequence of the events (see $8 \mathrm{~b}$ ). The other parts of the utterance contain DSAs with the forms of the present tense in the function of the usual present (8а: нахӧ ть д'Ттн нашн глазкы стекланын; 8b: тако творать по вса Аज̈H).

\section{Statement Concerning the Present (the Present Gnomic)}

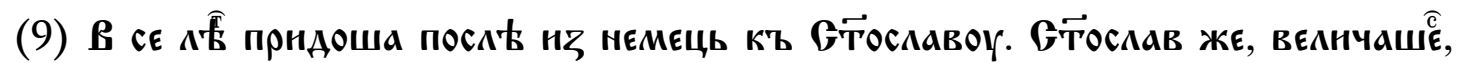

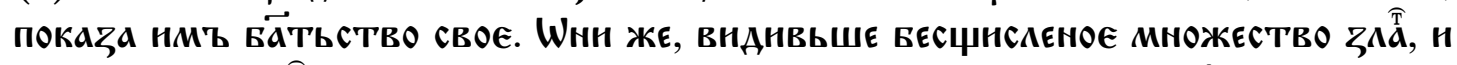

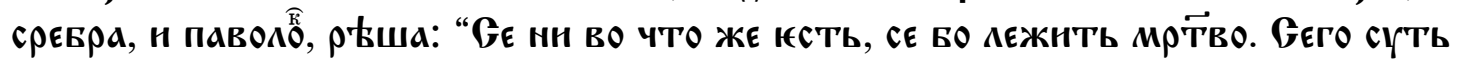
смьтье аүчьше. Мүжи в

The ambassadors, responding to the approval of Prince Svyatoslav, point out that the warriors are more valuable, meaning not a single action in the future but their ability to commit the action. 


\section{Statement Concerning the Decision}

(10) (а) И РЕ ЕМУ ШАННЪ КУАЕСННКЪ: "КНАЖЕ! КОНЬ, ЕГОЖЕ МЮБНШН Н КЪАНШН на нем

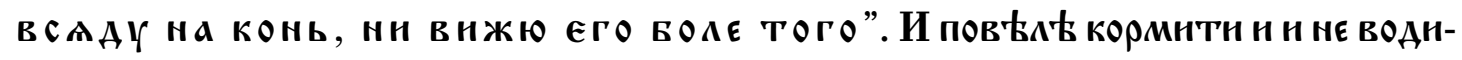

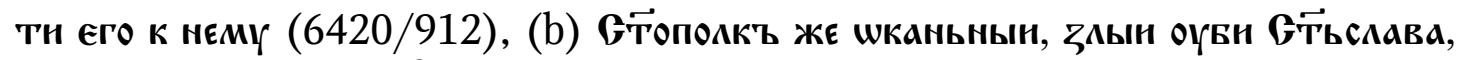
пославь кь гор' Оугорькон, в Бжацу ему вь оугры. И нача помышлАтн, гако: "Извью всю вратью свою и прннму валсть рускую еаннъ". По-

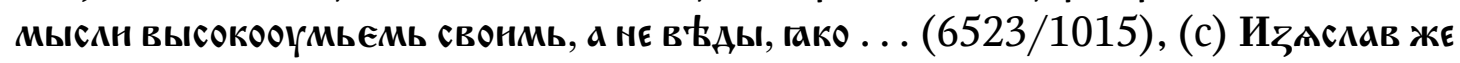
НАЕ В ААХЫ СО НМ ВННЕМЬ МНОГНМЪ Н СЬ ЖЕНОЮ, ОУПОВАГа БАТТЬСТВОМЪ МНОГЫМЬ,

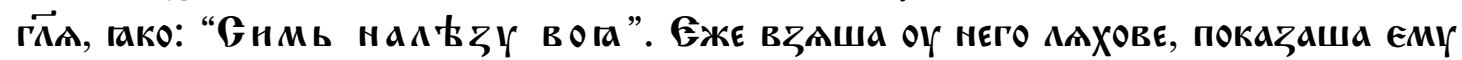

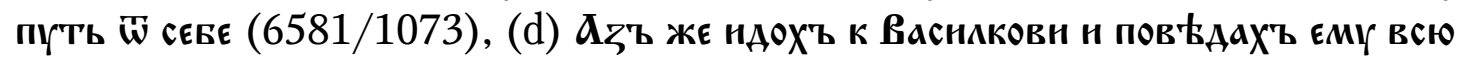

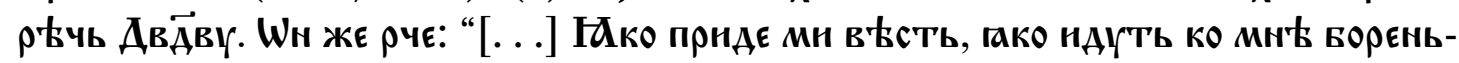

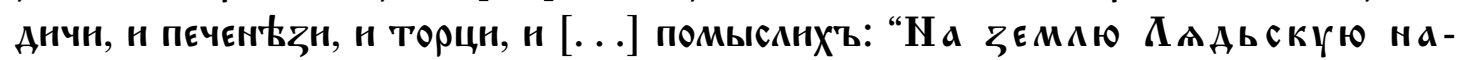

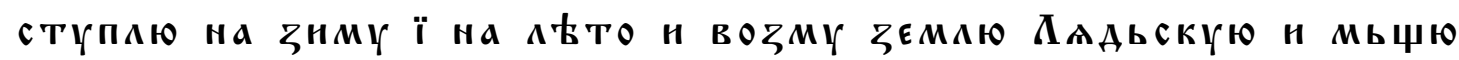
земкю Русьскую” (6605/1097).

The speaker utters his decision to perform an action in the future or to follow a certain pattern of behavior. More often than not, these utterances are addressed to the speaker himself: the narrator introduces the thoughts of the character to the reader, verbalizing his "inner speech." This theory is backed up by the fact that it is mentioned in the framework construction

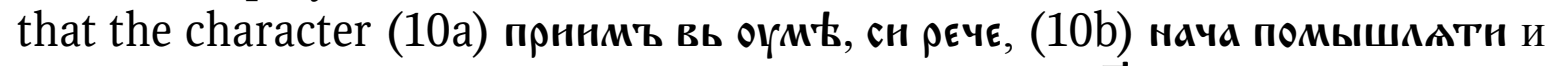
ПОМЫСАН ВЫСОКООГМЬЕМЬ СвОНМЬ, (10с) НАЕ ОГПОВ АГа Бӓ ТЬСТВОМЪ МНОГЫМЬ, (10d) прнде мн в'стть и помысанхъ. Example (10d) is the most illustrative because in this example, it is not the narrator but the character himselfPrince Vasilko-who tells his interlocutor about his thoughts, seeing them as the reason for the misfortunes he had to endure: व нноє помышиєнье въ срици

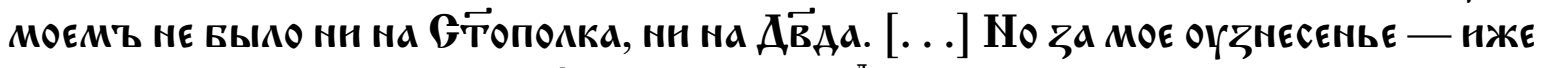
ПОНАОША БЕРЕНЬАНЧН КО МН', Н ВЕСЕААСА СР̆ЦЦЕ МОЕ, Н ВЪЪВЕСЕАНСА ОУМЪ МОН,

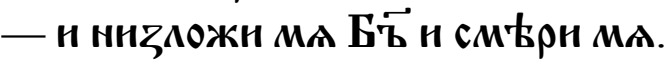

\section{Call for Action}

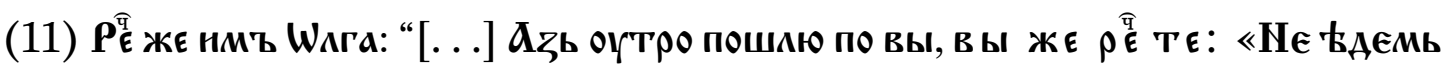

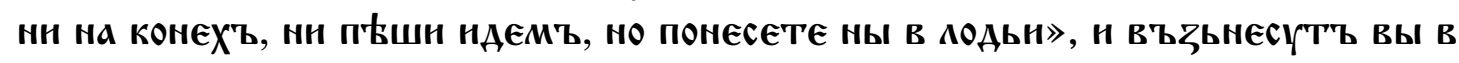

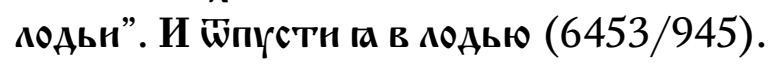

The form of the future tense describes the action Princess Olga encourages her interlocutor to perform. As in (4a), (4b), (5a), and (5b), the speaker uses the ISA as a rhetorical device, allowing them to "impose" their point of view on the recipient. 
5. Call for Joint Action

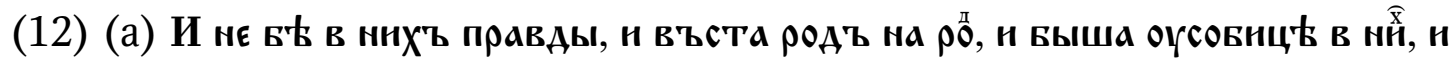

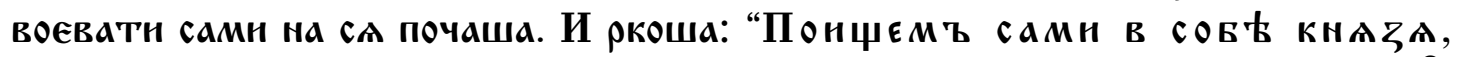

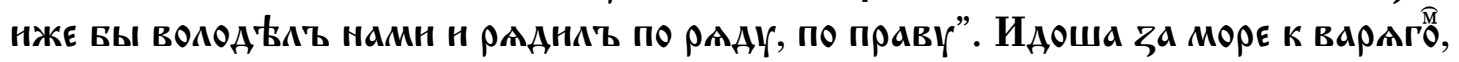
к русн (6370/862), (b) И въСПАШа ПрЕ ПаволочнТЫ', а словТне КрОПнНнНЫГа,

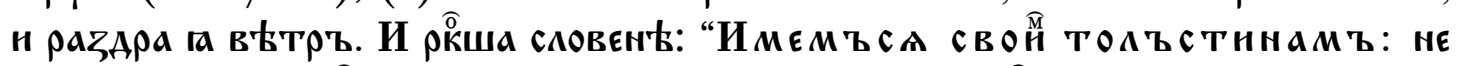

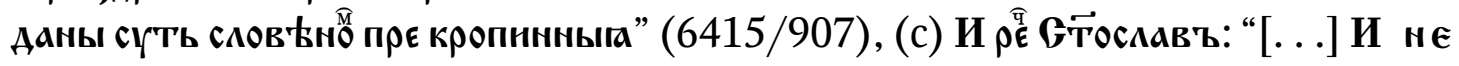

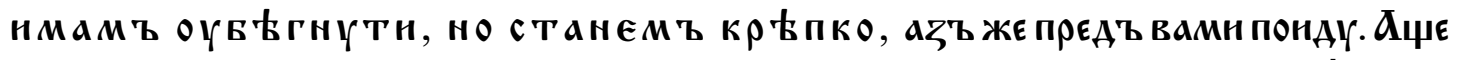
MOГА ГААВа ААЖЕТЬ, ТОЖЕ ПРОМЫСАНТЕ W СЕБ'". И РКОША ВОН: "ИАЕЖЕ ГААВ̈ ТВОГА ААЖЕТЬ, ТУ И ГААВЫ НАША САОЖЙ" (6479/971), (d) ЭТТОСАаВЪ ЖЕ ПрНГа АарЫ И ПОЙ

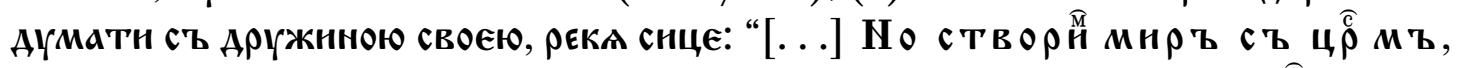
СЕ БО НЫ СА ПО ААНЬ ГААЪ, И ТО БУАН АОВОАНО НАМЪ. [...]”. И АЮБА БЫ

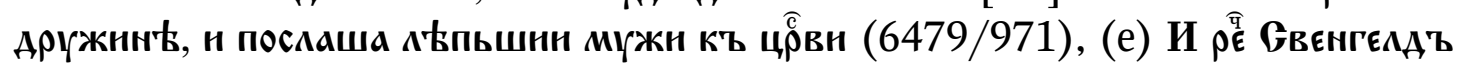

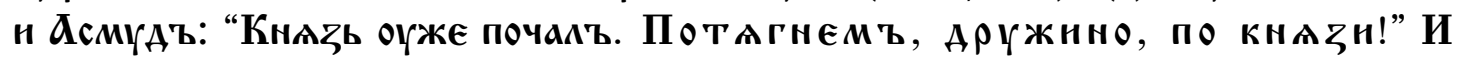

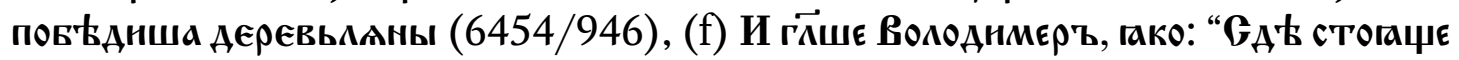

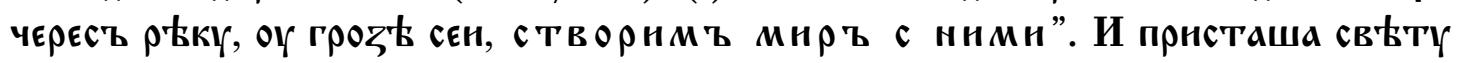

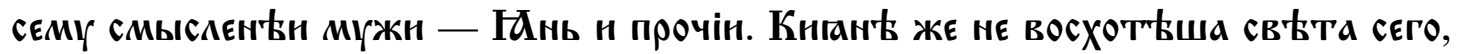
но рекоша: "Хоцемъ са внтн. Поступнмъ на шну сторону рҺк'” (6601/1093).

ISAs with the forms of the future tense are used to encourage the interlocutor to perform a joint action, the speaker and interlocutor constituting a single social group. ${ }^{6}$ In some cases, this group is undifferentiated $(12 \mathrm{a}, 12 \mathrm{~b})$ : the utterance of such statements demonstrates the making of a common decision concerning further actions, which labels such statements as self-addressed ones (the whole group is specified as the speaker), and which brings these statements closer to those described in (10). In some other cases, the "head" of the group appeals to all the rest. If the recipient accepts the call, the chronicler

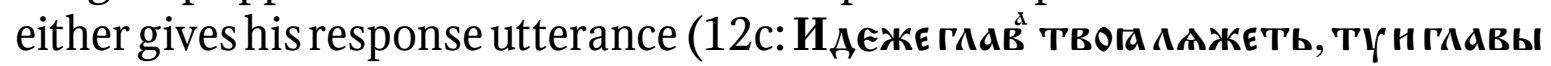
наша сложй-a response utterance of the warriors, motivated by the second part of Prince Svyatopolk's speech, expresses their consent to follow him to the end); or gives the response of the recipient in the frame construction (12d: $\mathbf{n}$ Аюга вьі рьчь сї аружнн'); or says nothing, giving the reader an opportunity to withdraw the implicit information from the correlation of the appeal and

6 We believe that there is no reason to speak about the use of certain specific 1st person plural forms of the imperative, "homonymous" to the 1st person plural forms of the future tense, in the given paragraphs: otherwise researchers would have to define specific "homonymous" forms for each case of the use of verbal forms in a figurative (i.e., non-direct) sense. The morphemic structure of these forms in the chronicles shows that they are not the etymological forms of the imperative, and the use of the present or future tense forms to express inducement, as pointed out by A. I. Sobolevsky [СоБолЕвский 2005: 253], seems quite natural, since we mean an action that the speaker intends to perform immediately after the speech act or in the near future, and wants to involve his interlocutor in it. The fact that these forms are not grammatically formed as imperative indicators, such as the modern nойдем vs. пойдемте, is essential. 
the descriptions of the subsequent actions (12е: н пов Ванша деревьланы). ${ }^{7}$ If the recipient does not agree with the call-which is a rare case-the narrator states this in the frame construction and gives an utterance explaining the disagreement of the interlocutor (12f: Кнган' же не восХот'ШШа св

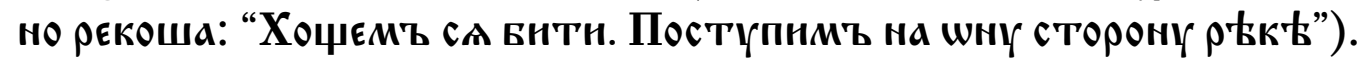

All ISA forms of this type contain the forms of the 1st person plural, with most statements containing clichés uttered in typical communicative situations ("the discussion of 'the search for' the Prince": Понцємъ!, Понмемъ!; "the speech of the headman, calling to make peace with the enemy"; Отворнмъ мнръ!). It is characteristic that six of fourteen ISAs with IF "call for joint action" contain a cliché Потагнемъ! (Пондємь!), and the information about the consent of the recipient is given as implicit information (see 12e)-this way of describing events characterizes the speech genre of "a warlord addresses his warriors before a battle."

6. Institutional Statement

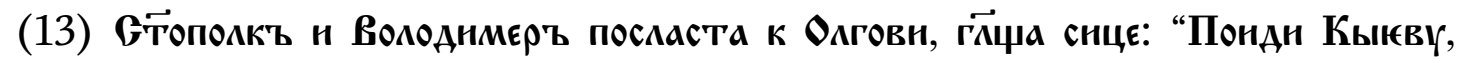

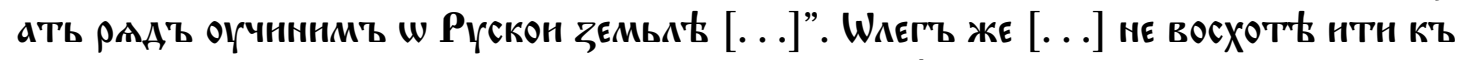

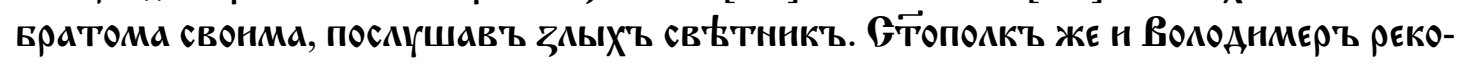

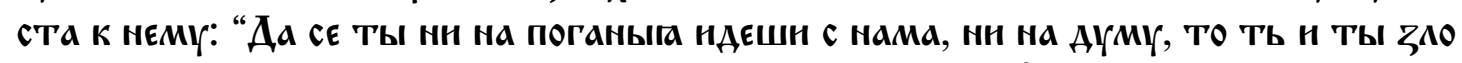

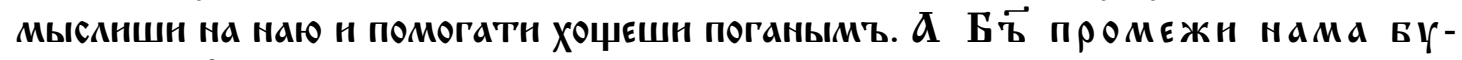

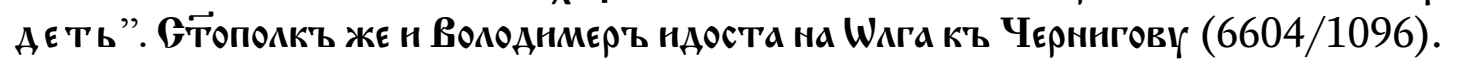

Just as in (6), the speaker sets the standard (Бог нас paccydum), which will henceforth determine the relationship between the dissenting brothers-princes.

7. Promise (Oath)

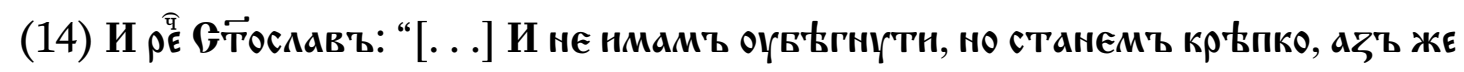

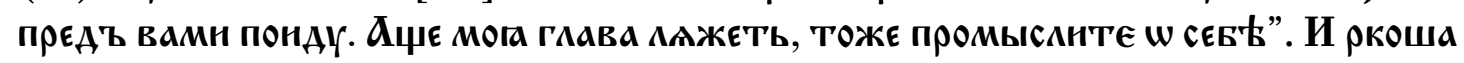

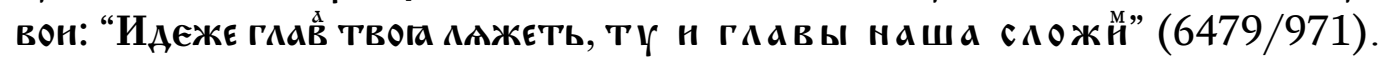

Uttering a response statement, the warriors do not report about possible future events, but swear allegiance to Prince Svyatoslav.

\section{Report of an Event that did not Happen due to the Non- implementation of a Certain Condition \\ 1. Evaluative Judgment, Condemnation of the Events of the Past}

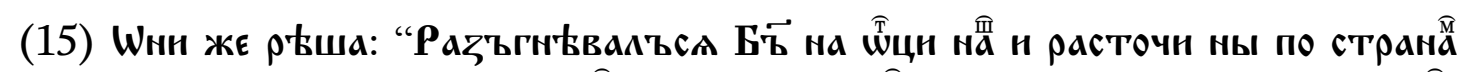

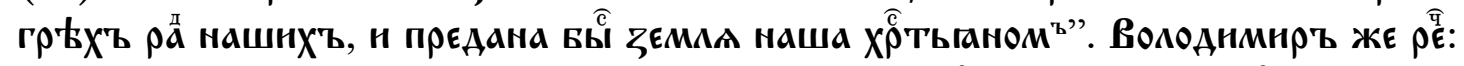

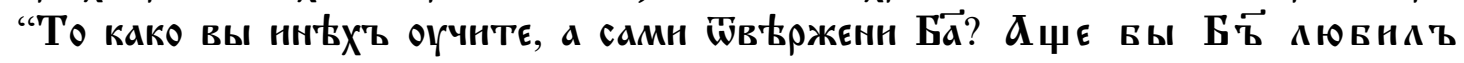

\footnotetext{
7 The latter method of description is the most frequently used one.
} 


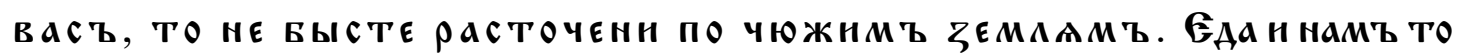
ЖЕ мысАнте ЗАо прї̈атн?” (6494/986).

The utterance states, Вы рассеяны по чужим землям, потому что Бог не любит вас. It should be noted that the understanding of the ISA in this case is impossible without reference to the content of the two parts of the utterance: the speaker describes a situation exactly the opposite to the one which is true (Выне были бы рассеяны по чужим землям vs. В действительности вы рассеяны по чужим землям), which gives a pejorative connotation to the views expressed in the second part of the structure (Бог любил бы вас vs. $B$ действительности Бог не любит вас).

All the statements given above are non-interrogative. As we can see, in most cases their use as an ISA is associated with the use of special verbal forms. Present forms are used in constructions describing events that took place prior to the moment of speech or the events that, according to the speaker, should occur in the future, and the degree of probability of their implementation is estimated differently. Future tense forms express the meaning of the usual present and the gnomic present, and are also used in the constructions describing future events, the implementation of which seems problematic to the speaker, which makes him add to them a modal evaluation. It is characteristic that the use of past tenses in mono-functional ISAs is extremely rare. ${ }^{8}$ Example (15) may be considered as an exception-a statement that describes the condition in which the past situation would not have emerged. Thus, the use of mono-functional non-interrogative ISAs is primarily related to the changes of the semantics of the verb forms-in terms of tenses or modality.

\section{Call for Information (Verifying Question) \\ 1. Call for ACTION}

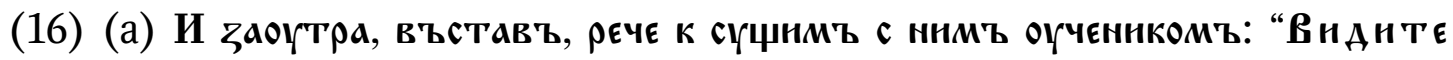

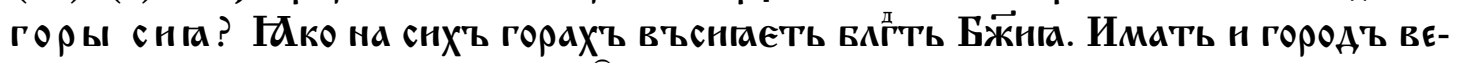

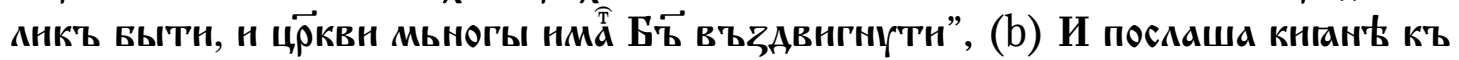

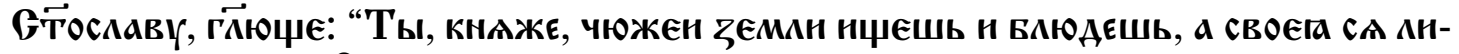

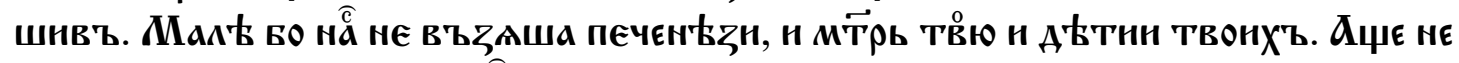

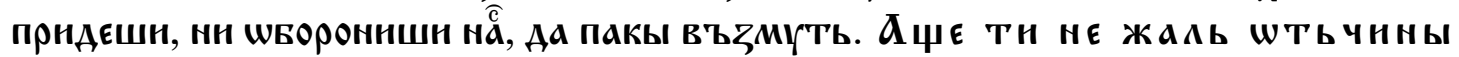
своега, и м түрь, стары сүща, и аъти свой?” То слышавъ, G Тославъ

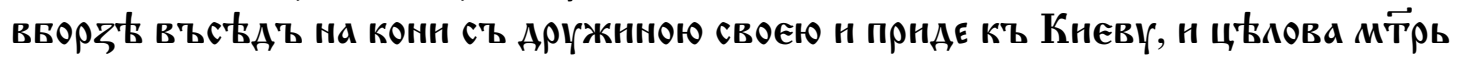

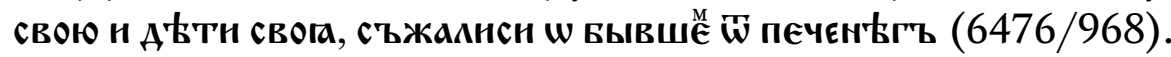

Uttering an interrogative sentence, St. Apostle Andrew encourages his disciples to look in the necessary direction. The citizens of Kiev do not want to

8 At the same time, they can be found in the poly-functional ISA; see [СоБолЕвский 2005: 253]. 
know if Prince Svyatoslav has pity either for his own homeland or for his loved ones, but urge him to have pity for them, and manage to put their message

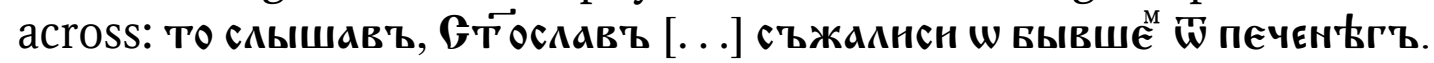

The example (16b) is characterized by a feature already mentioned in (15) and characteristic of the majority of interrogative ISAs (both verificative and informative): the utterance with a negation should be seen as an affirmative one and vice versa (Тебе не жаль? > Пожалей!). ${ }^{9}$

\section{Evaluative Judgment}

(17) (а) И прндоша вь Градъ, и рекаша мюдне: "ПочтО ГүБНте севе? КОАн

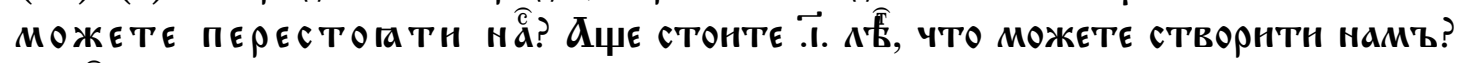

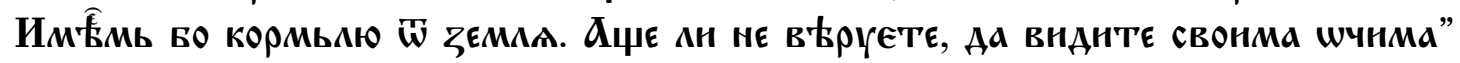

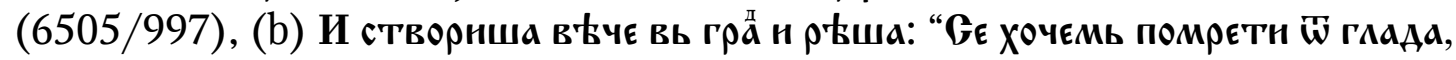

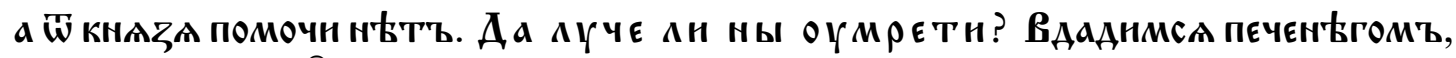

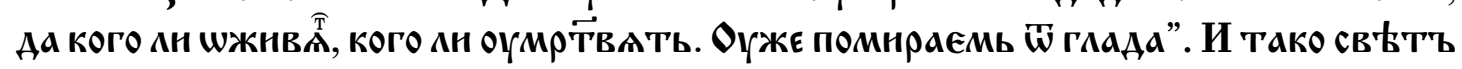
створнша $(6505 / 997)$.

The speaker expresses his judgment on the impossibility of performing an action in the future (see 17a) or that it would have negative consequences (17b).

3. Reminder

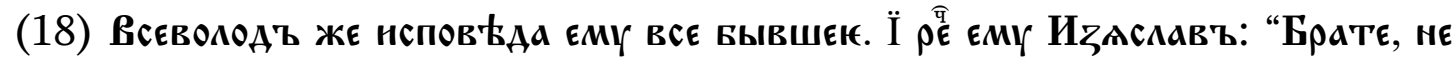

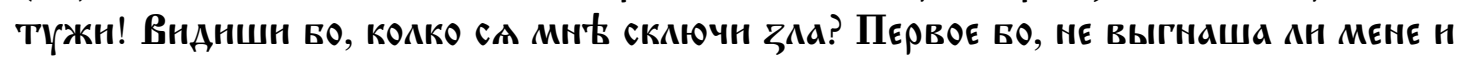

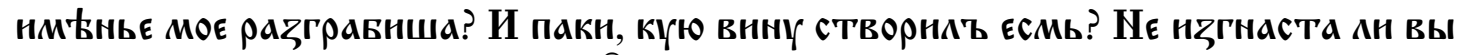

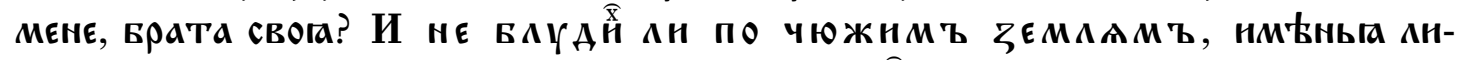

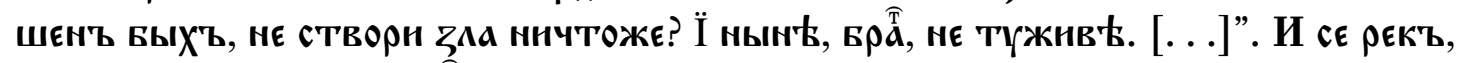

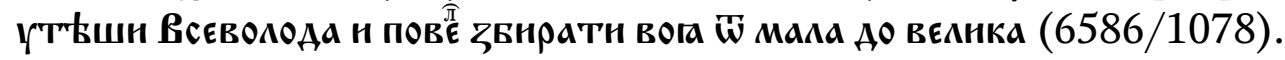

It should be pointed out that the IF "reproach" detected in connection with the whole utterance (18) is derived from the correlation of this syntagm with other syntagms, complementing it: if these "additional" syntagms were not pronounced, the statement would not be understood as a reproach (cf: И нє

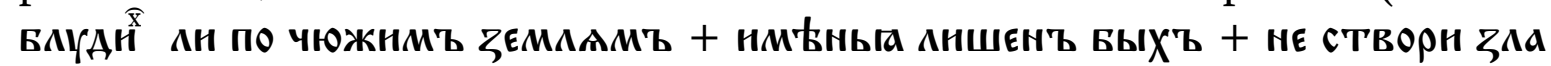
ннчтоже? > Я скитался по чужим землям, хотя и пострадал безвинно: меня лишили имущества, хотя никакого зла я не сотворил vs. *И не Бмүан̆ Ан по чнжнмъ земкамъ > Я скитался по чужим землям). Thus, this additional IF is characteristic of a complex of speech moves ${ }^{10}$ rather than of each taken individually, and therefore the ISA (18) should not be considered a poly-functional statement.

9 This feature of the interrogative ISA will be given more attention after the description of the ISA of the given type.

${ }^{10}$ Read more about the elementary and complex speech moves and turns in [СоБолЕвский 2005: 253]. 
In contrast to (18), the utterance in the same question Нє выгнаша мн мене и нмьнье моє разгравнша? is poly-functional: the speaker simultaneously reminds his brother of the past and reproaches him, and each PU, constituting a statement, is seen as a reminder and as a reproach, even if the second PU is "removed."

The utterance Не ндгнаста ан вы мене, врата свога? is more difficult. On the one hand, the IF "rebuke" is set by correlating the contents of two syntagms, constituting a complex speech move (Не нзгнаста ан вы мене + врата свога? > Вы поступили плохо, изгнав своего брата). On the other hand, even if the second part of the structure is omitted, the first will be illocutionarily poly-functional due to its personal mode of address: the subject of a proposition, describing a negatively evaluated event, coincides with the recipient, and therefore this part of the statement is perceived as a reminder and as a reproach (*Ае нггнаста ан вы мене? > Это вы меня изгнали). The second part of the structure, because it is not propositive, has no illocutionary polyfunctionality, but is communicatively significant: it does not allow the recipient to doubt that the speaker is turning his attention to his being involved in a negatively evaluated action.

4. Call for Information (Informative Question)

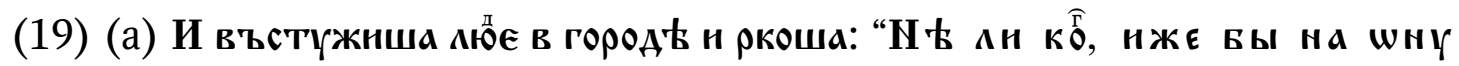

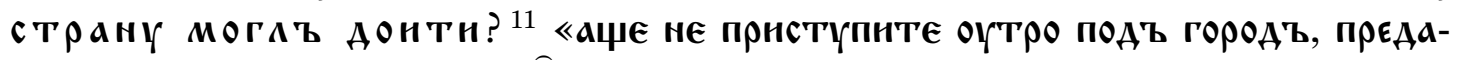

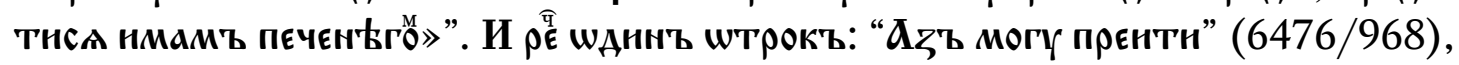

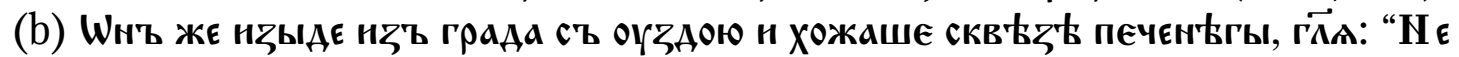

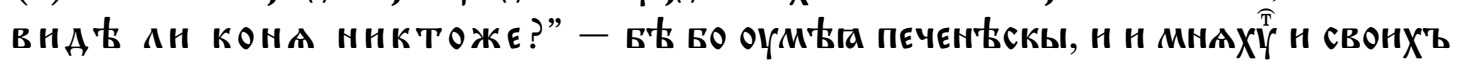
(6476/968).

ISAs (19a) and (19b), as formally negative utterances which require the validation of the stated information, are actually pronounced in order to see who can be the agent of the proposition described in the utterance (the pronouns кто and ннкто are used in the same function): Нет ли кого, кто мог бы ...? should be seen as Кто может . . . ? and Никто не видел коня? means Кто видел коня?

\section{Information Required (Informative Question) \\ 1. Evaluative Judgment}

The ISAs of the given type can be observed in the Tale of Bygone Years most frequently. They often include pronominals in the cataphoric function, which replace the syntactic positions in the predicative units [PU]. These syntactic positions can correlate both with nouns and with proposition predicates.

\footnotetext{
${ }^{11}$ Laurentian Codex: add. и
} 


\section{A. Utterances with $\mathbf{K} \mathbf{T O}$}

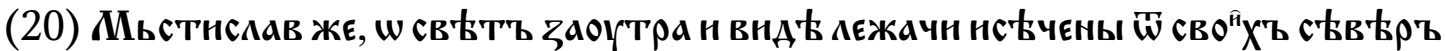

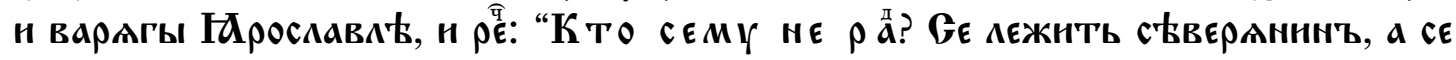
вараГ"Ъ, а свога дружнна ц'Һла” (6532/1024).

The pronoun кто refers to the grammatical patient in the position of the subject.

\section{Utterances with $\mathbf{Y T} \boldsymbol{O}$}

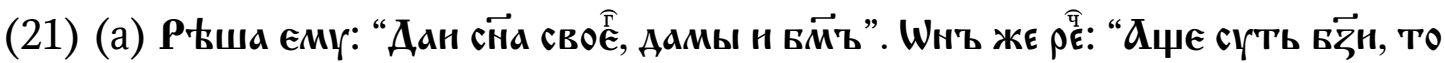

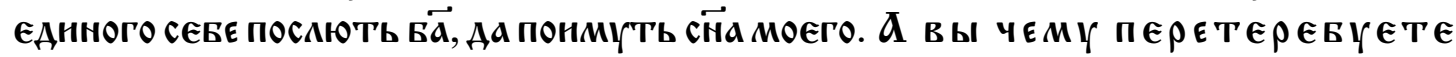
и м ъ?" И клнкнуша и "осъкоша сьнн подъ ннмн, и тако повнша га (6491/983),

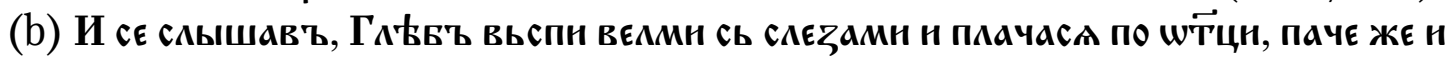

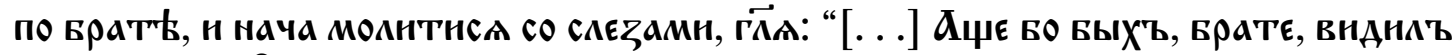

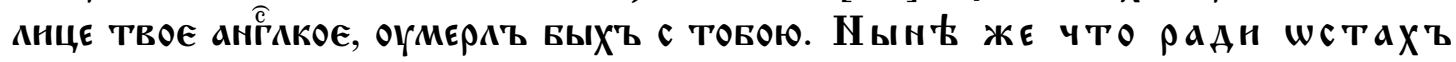
аъъ ЕАннъ? [...]" (6523/1015), (с) И рҺша ему что вы распрю нмата межн совою, а поганин ГуБать бемаю Рус-

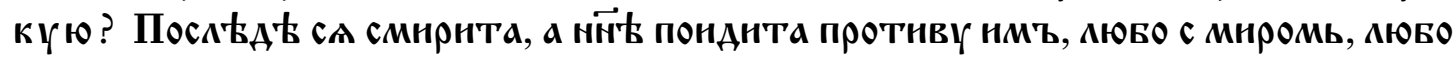
раТЬю" (6601/1093), (d) УРОПОЛКЪ ЖЕ НААШЕ ПО нЕМЬ, ПААЧАСА СЪ АРУЖННОЮ

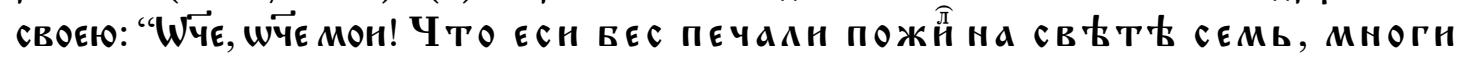

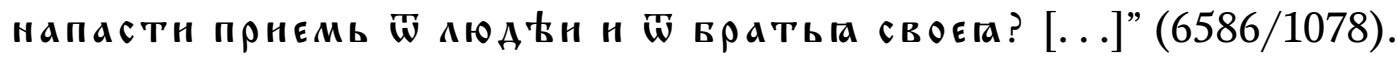

The use of the pronoun что (21a: чему; 21b: что радн; 21с: по что) with or without prepositions is mainly connected with the expression of the meanings of cause and motive, but, at the same time, they cannot be differentiated. The use of the pronoun что in (21d), where it expresses a quantitative meaning, should be mentioned as an individual case.

\section{Utterances with $\mathbf{K} \mathbf{\mathbf { K } \boldsymbol { 0 }}$}

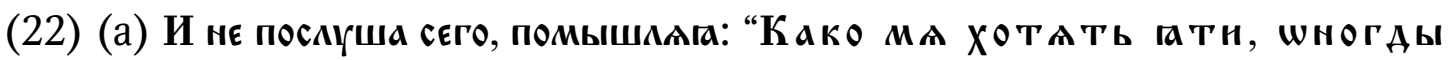

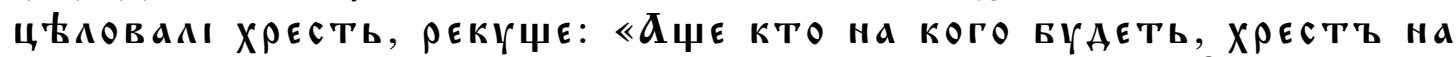

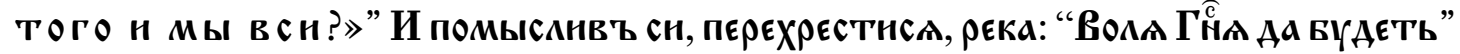

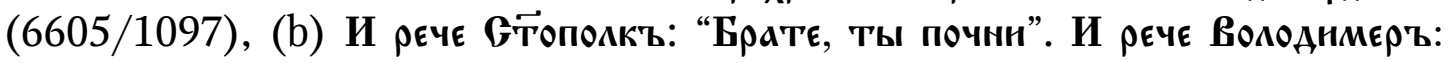

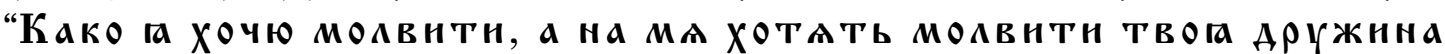

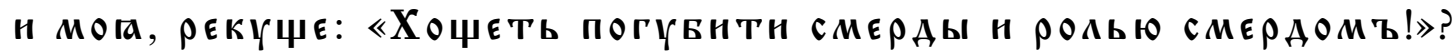

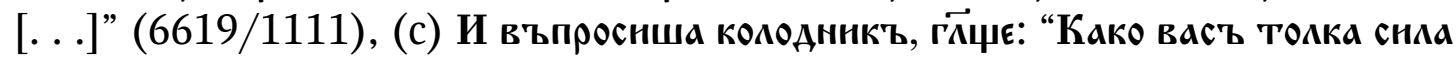

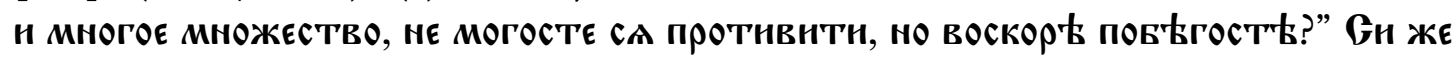

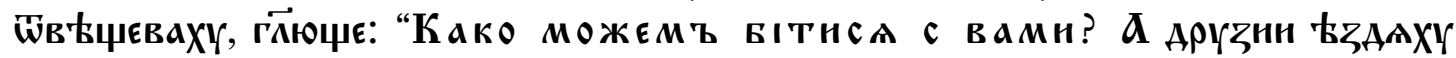
верХУ васъ въ шрУжьн свЪТА' и страшнн, нЖе помагахУ вамъ!” (6619/1111).

In all ISAs, which include the pronominal adverb како, there can be observed predicates which consist of a modal verb and the infinitive of a notional verb. At the same time, the PU which includes како describes the event which is

12 Laurentian Codex: има. 
being evaluated and the implementation of which is 'limited' by the condition, stated in the following PU.

The utterances which include the verb хот' refer to the intention of the subject of the proposition to take action, expressed by the infinitive, either at some time after the moment of speech (see 22a) or shortly after the given utterance was made (see 22b). In the second case, the speaker evaluates the possibility of taking the verbal action, which he, supposedly, does not dare to take (Какжемне говорить, если...): this so-called masking strategy of both speech and behavior allows him to express his point of view and, at the same time, to forestall the possible objections of the interlocutor.

In (22c) the modal verb мочи is used. It is remarkable that although the given event took place in the past, the speaker uses the form of the present tense as in (22a) and (22b) in the meaning of the gnomic present.

\section{Utterances with Кии}

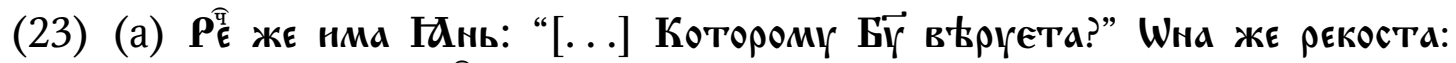

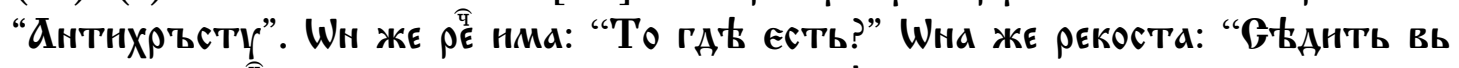

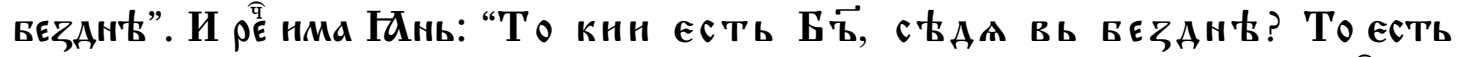

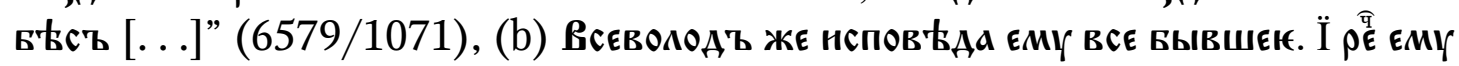

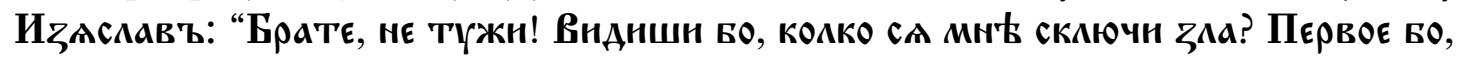

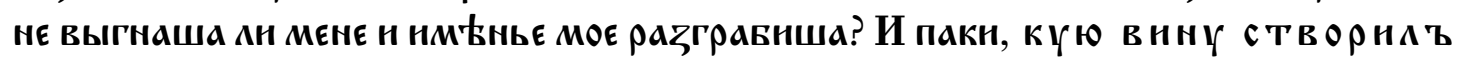
єсмь ? [...]" (6586/1078).

The pronoun кни takes the position of an attribute of the noun, the truthfulness of its denotative meaning is somehow discredited by the speaker (the Magi's god is not god, thus, the fault of Izyaslav is not a fault).

\section{E. Utterances with $\mathbf{K A} \mathbf{6}$}

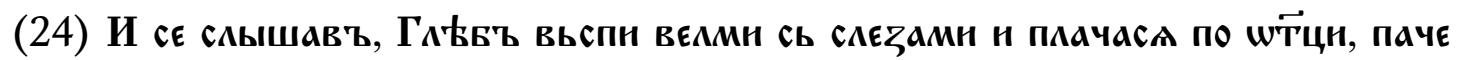

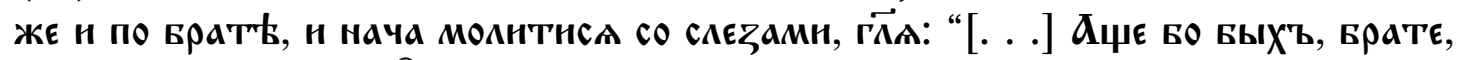

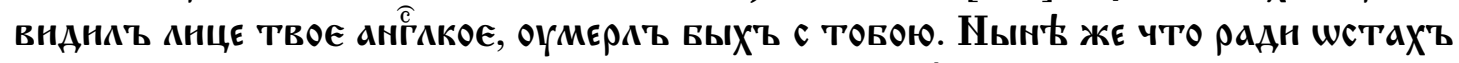

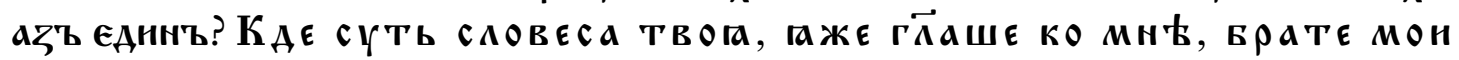
Аювнмын? [...]” (6523/1015).

The ISA with the pronominal adverb кAє [where] is observed in the same passage as (21b). The use of two ISAs, one after another, allows the speaker to express the sorrow he feels after he lost his beloved brother.

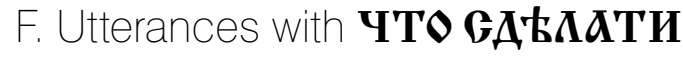

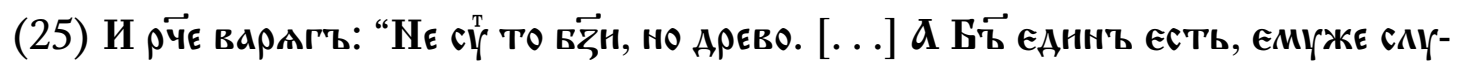

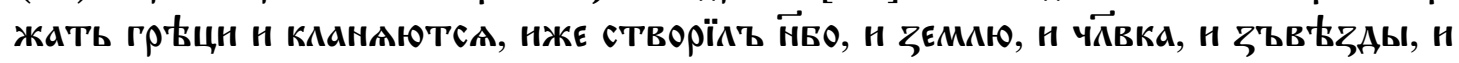

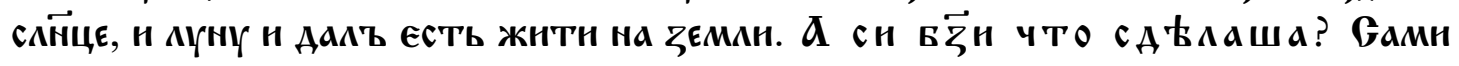
А'ҺАанн сүтт. [...]" (6491/983). 
The pronominal use of a verb can also be observed in the TBY: the predicative combination (predicative complex) что с $\mathbf{A}$ 'каша replaces those predicative combinations that could have been used in the response utterance if the speaker's question had not been an ISA, implying that pagan 'gods' did nothing [ничего не сделали].

\section{Reminding of the Past, Stating Intentions, and Describing the Current Situation and Affairs}

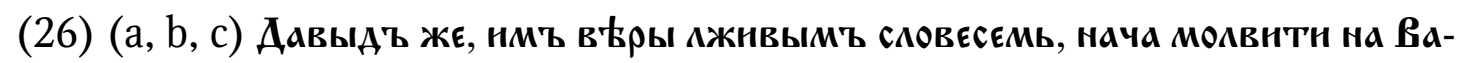

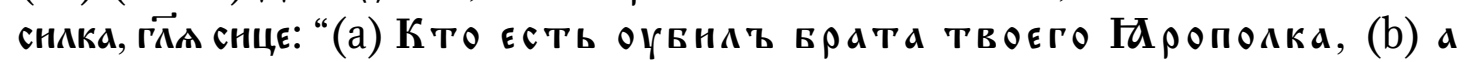

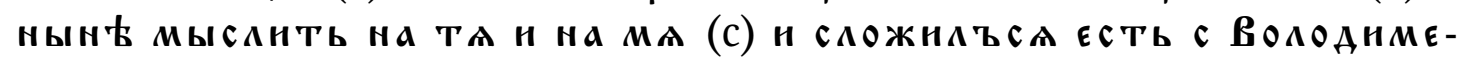
рОмъ? АА ПрОМЫШААН СН Ш СвОЕН ГОАОвЪ!" (6605/1097).

Example (26) presents a number of ISAs united by a common agent and expressed by the pronoun кто. Example (26a) reminds the interlocutor of an action, which the person they talk about committed earlier; (26b) states his intention; and (26c) speaks about the current situation, which is the result of his previous actions. Correlation of the propositive meanings of these three PUs should make the interlocutor consider the speaker's words as a warning (26a, 26b, and 26c cannot be regarded as a warning individually), moreover, the given IF is also typical of the PU Аа промышлан сн ш своєн голов't--the utterance, used here as a DSA.

\section{Unfavorable Forecast}

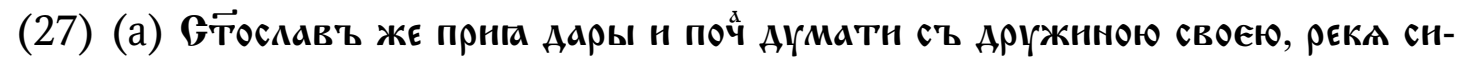

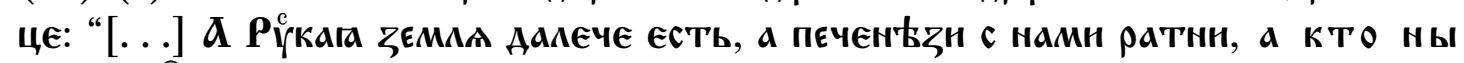

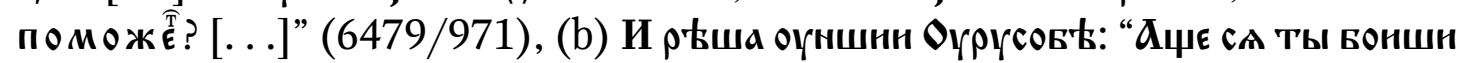

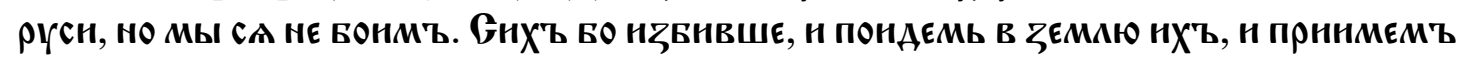

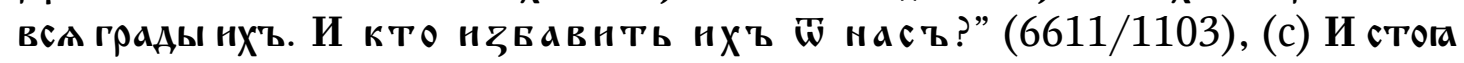

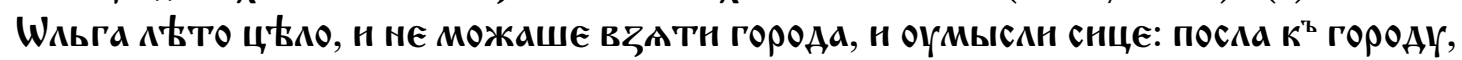

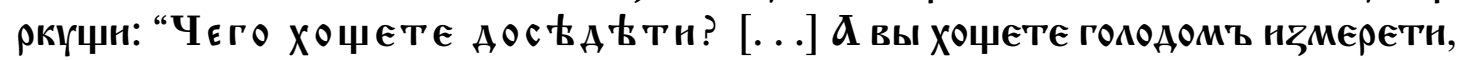
не нмучнсА по дань" (6454/946), (d) И прНАОша вь Градъ, И реКаша пюдне:

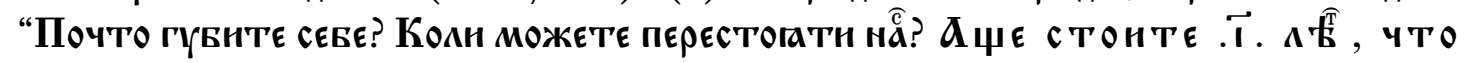
Можете створнти намъ? [...]" (6505/997).

In examples (27a) and (27b), the pronoun кто refers to the agent. In example

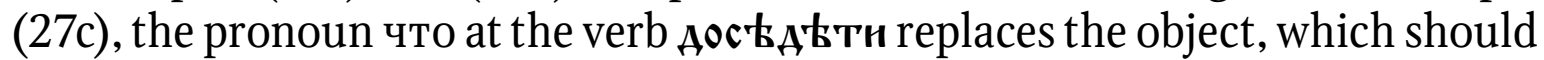
be taken as a proposition (at the end of the utterance, made by Princess Olga, this proposition is verbalized: вы хочете голодомъ измеретн). In (27d), a pronominal verb is used (comp. to 25).

It should be stressed that (27a) is a forecast unfavorable for the speaker; (27b) for the participant of the proposition who is not a communicant; and (27c) and (27d) for the interlocutor. 
4. Apprehension

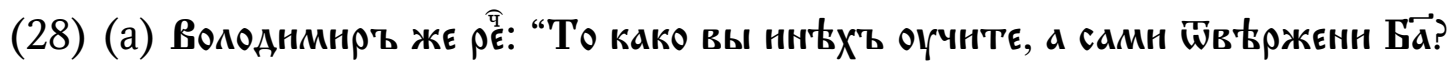

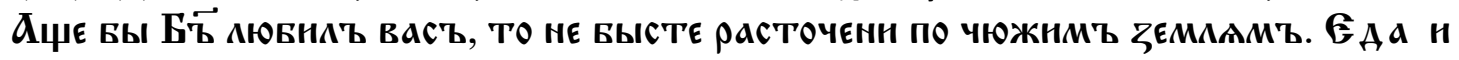

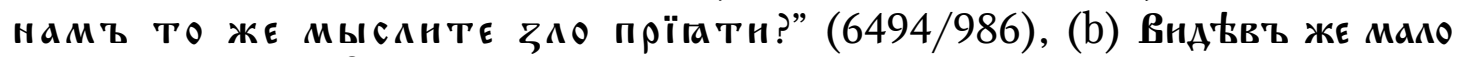

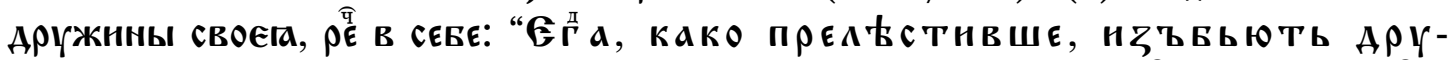

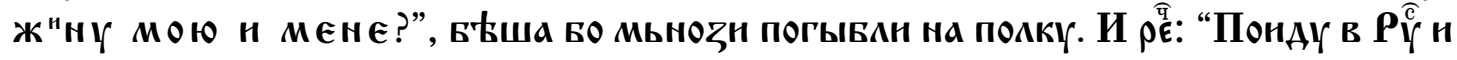
ПрНвеАУ БОЛЕ АРГЖННЫ" (6479/971).

The speaker expresses apprehension that the event unfavorable for him can take place. At the same time, he addresses his utterance either to the interlocutor (see 28a), or to himself (see 28b): in the second case, as in (10), the narrator verbalizes the 'inner speech' of the character, showing its specific nature in the frame construction ( $\rho \in \bar{\epsilon}$ в сєЕв). ${ }^{13}$

\section{Hope}

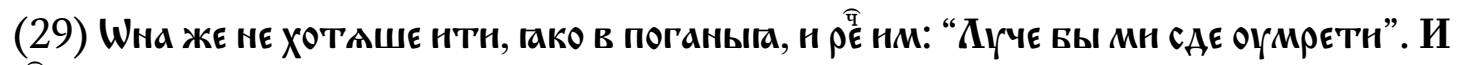

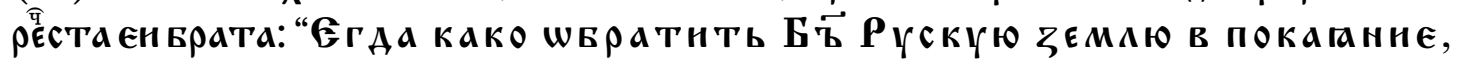

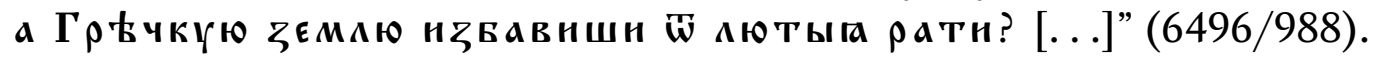

In contrast to (28b), the speaker expresses his hope that the mentioned event will take place; in both cases the conjunction erAa is used, but at the same time its meaning is so different from the meaning of a time conjunction "when" $\kappa о г \partial a$ that there is a question as to whether these interrogative utterances are verificative. However, attention should be paid to the fact that both in (28) and in (29), the participants of communication speak about future events, and the possibility of their implementation is the subject the speaker is really worried about. It is the combination of two time zones-the moment of speech and the event following it-that accounts for the use of a time conjunction.

\section{Call for Information (Combination of Verifying and Informative Questions)}

A number of TBY passages include constructions where two ISAs are used together: the verifiable question, the IF of which is 'calling to an action,' and the informative question, the IF of which is the 'evaluative judgment':

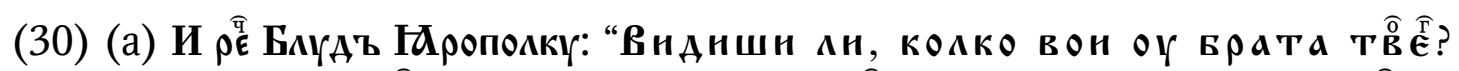

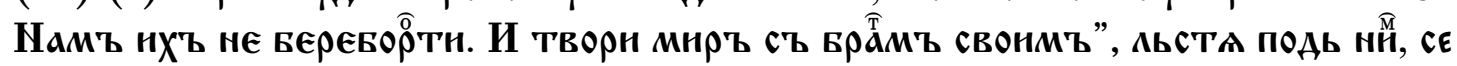

13 It should be pointed out that the conjunctions $\mathbf{e r}_{A} \mathbf{a}$ and $\boldsymbol{\epsilon}_{A} \mathbf{a}$ are used synonymously in the given fragments (this feature was noted by I. I. Sreznevsky, who used the contexts in the given type of ISAs as examples; see [СРЕзнЕВский 1893: 807, 808]). Particularly, they can be used in the same sentences in various chronicles; thus, in the fragment Ркоша же аружина Игорева: “Аа аџе снце ГАТТ Ц̆рь, тО чтО ХОџемЪ БОле

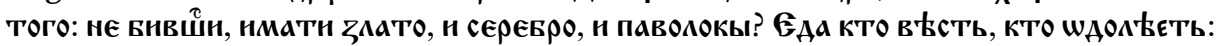

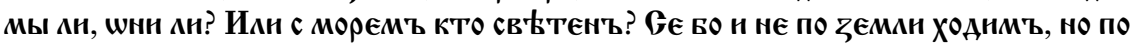
глувин' морьстин, н швьча сиртть всьмъ” (6452/944), the conjunction єда is used in the Hypatian Codex and єгда is used in the Laurentian Codex. 


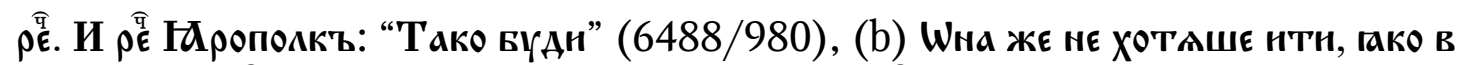

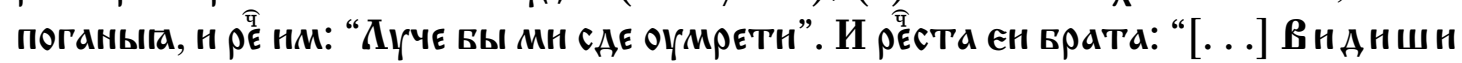

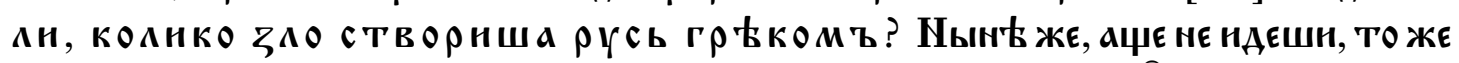

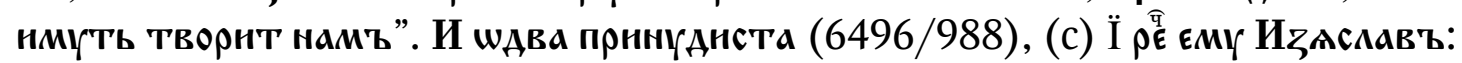

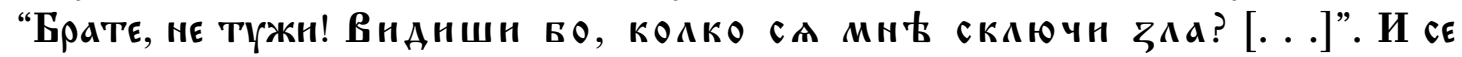

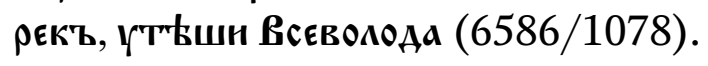

In all of these utterances the first position is taken by the ISA in the form of the 2nd person present tense внднши, which forms the mental modus structure: ${ }^{14}$ the interlocutor, supposedly, evaluates the current situation himself, although in fact the speaker adduces his own point of view, which is expressed by the following ISA with the pronoun комко, meaning a great number/amount of the evaluated thing: (30a: Сколько воинов? = Много воинов; 30b и 30с: Сколько зла? $=$ Много зла). ${ }^{15}$

It should be pointed out that such 'compound' ISAs are observed in dialogues in which the speaker, by means of changing different strategies of speech and behavior, ${ }^{16}$ tries to convince the interlocutor of something, and each time he succeeds. Thus, the chronicler regards 'compound' ISAs as utterances that allow him to achieve the perlocutive effect he wants in a discussion the result of which is not obvious.

Concluding the analysis of interrogative ISAs, let us once again discuss the feature that has been discovered when describing example (16b). As we can observe, in most cases the use of interrogative utterances as ISAs is connected with the following semantic changes in the propositions:

- if an utterance, which is understood literally, expresses a negative judgment (formally, it is expressed by the negative particle нє), it should be interpreted as a positive one (16b: Тебе не жаль? > Пожалей!; 18: Не скитался ли я по чужим землям? = Я скитался по чужим землям!; 19а: Нет ли кого, кто мог бы. . . ? = Кто может. . . ?; 19b: Никто не видел. . . ? = Кто видел. . . ?; 20: Кто этому не рад? = Все этому рады!),

- if an utterance, which is understood literally, expresses a positive judgment, it should be interpreted as a negative one (17a: Можете ли вы перестоять нас? = Выне можете перестоять нас!; 17b: Лучше ли нам будет, если мы умрем? = Если мы умрем, нам лучше не будет!; 21а: Зачем вы совершаете им

${ }^{14}$ Compare with (16a), where the verb is used in its literal sense.

15 This reveals a pattern: in cases when, determining the number of the positively evaluated object, the speaker refers to the lack of it (see 21d: Сколько ты без горестей пожил на этом свете? = Мало ты пожил на этом свете без горестей!), and in cases when, determining the number of the negatively evaluated object, the speaker refers to its redundancy (see 30a, 30b, and 30c).

${ }^{16}$ Concerning speech behavioral tactics, see [ВЕРЕЩАГИН, КостомАРОв 2005: 524, 525]. 
требы? = Вам незачем совершать им требы!; 21b: Зачем я остался один? = Мне незачем оставаться одному!; 21с: Зачем вы ссоритесь? = Вам не следует ссориться!; 22а: Как же меня собираются схватить, если. . . ? = Меня не могут собираться схватить, поскольку. . .!; 22b: Как же я буду говорить, если...? = Я не могуговорить, поскольку. . .!; 22с: Как мы можем биться с вами, если...? = Мы не можем биться с вами, поскольку... !; 23а: Какой это Бог. . .? = Это не Бог. . . !; 23b: Какой я проступок совершил? = Я никакого проступка не совершал!; 24: Где твои речи. . .? = Твоих речей больше нет. . .!; 25: Что эти “боги” сделали? = Эти “боги” ничего не сделали!; 27a: Кто нам поможет? = Никто нам не поможет!; 27b: Кто избавит их от нас? = Никто не избавит их от нас!; 27с: Чего вы хотите дождаться? = Ничего хорошего вы не дождетесь!; 27d: Что можете нам сделать? = Ничего нам не можете сделать!).

Thus, as it has turned out, the feature that is so typical of modern Russian discourse has a long history and is quite traditional.

\section{Conclusions}

The analysis allows for the following conclusions:

1. The use of ISAs is typical not only of modern but also of Old Russian communication. ISAs in Old Russian can be used both as mono-functional and poly-functional utterances.

2. Mono-functional ISAs can be observed in 33 of 320 original (i.e., not observed in other texts) dialogue passages of the TBY. At the same time, more often than not, more than one ISA is used in a certain dialogue passage: the total number of mono-functional ISAs is 82 utterances.

3. The semantics of non-interrogative mono-functional ISAs (44 utterances) in most cases is connected with the expression of indirect time and aspect of verbal forms (present forms referring to events in the past, future forms to unreal events, and so forth).

4. 38 mono-functional ISAs are interrogative utterances. In the majority of cases their semantics is narrowed to the statement of a certain evaluative judgment; at the same time, in the structure of the proposition the semantic operator of negation is replaced by the semantic operator of assertion and vice versa.

5. The types of mono-functional ISAs, singled out in the course of the analysis, can be observed in modern Russian discourse as well, which allows us to assume that they are quite traditional.

\section{Bibliography}

ВЕРЕЩАГИН, КОСТОМАРОВ 2005

ВЕРЕЩАГИН Е. М., КОСТОМАРОВ В. Г., ЯзыК и культура. Три лингвострановедческие кониепции: лексического фона, рече-поведенческих тактик и сапиентемы, Москва, 2005. 
ЛАЙОНЗ 2003

ЛАйонз Дж., Лингвистическая семантика. Введение, Москва, 2003.

ПАДУЧЕВА 2001

ПАДУчевА Е. В., Высказывание и его соотнесенность с действительностью, 2-е изд., Москва, 2001.

ПСРЛ 1908

Полное собрание русских летописей, 2: Ипатьевская летопись, 2-е изд., С.-Петербург, 1908. 1926

Полное собрание русских летописей, 1: Лаврентьевская летопись, 1: Повесть временных лет, 2-е изд., Ленинград, 1926.

САВЕЛЬЕВ 2016А

САВЕльЕВ В. С., “Древнерусские иллокутивно полифункциональные высказывания: сообщения о бывшем, настоящем и будущем (на материале «Повести временных лет»)”, Вестник Московского университета. Серия 9. Филология, 2, 2016, 79-105. 2016ь

САВЕЛЬЕв В. С., “Функции глагольных форм настоящего времени в речи персонажей «Повести временных лет»”, Филология и человек, 2, 2016, 127-142.

СЕРль 1986

СЕРль ДЖ. Р., “Косвенные речевые акты”, in: Новое в зарубежной лингвистике, 17, Москва, 1986, 195-222.

СоболЕвский 2005

СоБолЕвСкий А. И., Лекции по истории русского языка, 5-е стер. изд., Москва, 2005.

СРЕЗНЕВСКИЙ 1893

СРЕзНевский И. И., Материалы для словаря древнерусского языка, 1, С.-Петербург, 1893.

\section{References}

Lyons J., Linguistic Semantics: An introduction, transl. into Russian, Moscow, 2003.

Paducheva E. V., Vyskazyvanie i ego sootnesennost' s deistvitel'nost'iu, 2nd ed., Moscow, 2001.

Savelyev V. S., "Old Russian Utterances with Illocutionary Multifunctionality: Communications about the Past, Present and Future (on the basis of 'The Tale of Bygone Years')," Moscow State University Bulletin. Series 9. Philology, 2, 2016, 79-105.

Savelyev V. S., "Functions of Present Tense Forms in Direct Speech in 'The Tale of Bygone Years', Filologiia i chelovek, 2, 2016, 127-142.
Searle J. R., "Indirect Speech Acts (transl. into Russian)," in: Novoe v zarubezhnoi lingvistike, 17, Moscow, 1986, 195-222.

Sobolevskiy A. I., Lektsii po istorii russkogo iazy$k a, 5$ th ed., Moscow, 2005.

Vereshchagin E. M., Kostomarov V. G., Iazyk $i$ kul'tura. Tri lingvostranovedcheskie kontseptsii: leksicheskogo fona, reche-povedencheskikh taktik $i$ sapientemy, Moscow, 2005.

Виктор Сергеевич Савельев, канд. филол. наук

Московский государственный университет им. М. В. Ломоносова, филологический факультет, доцент кафедры русского языка 119991 Москва, Ленинские горы, ГСП-1, МГУ, 1-й корпус гуманитарных факультетов, филологический факультет Россия / Russia alfertinbox@mail.ru 